\title{
KORELASI PENGATURAN SISTEM PEMILU PROPORSIONAL TERBUKA BERBASIS SUARA TERBANYAK DENGAN KORUPSI POLITIK DI INDONESIA
}

\author{
Oleh \\ Agus Riwanto \\ Fakultas Hukum Universitas Sebelas Maret \\ Email:agusriewanto@yahoo.com
}

\begin{abstract}
This research is aimed at studying and exploring about the relationship between the arrangement of election system adopted in Act No 8 Year 2012 on the election for the members of DPR, DPD and DPRD in 2014 general election and the practice of political corruption. The research is socio-legal research which integrates law norm with sociological aspect, applying approach method which put law principles and policial attitude. The result of the research shows that there is a positive correlation between the arrangement of open list proportional election with most number base and political corruption. As this system is highly cost, the candidates of legislative member happen to conduct deceitfulness in the election or what is classified as money politic to get support of the voters. The motive of political corruption conducted by the member of DPR and DPRD is to get back the high cost during the election. The renewal model of the election arrangement to creating political anticorruption is through purifying proportional election system by applying close list proportional system with serial number base.
\end{abstract}

Key words : correlation, proportional election system, political corruption

\begin{abstract}
Abstrak
Penelitian ini bertujuan untuk mengkaji dan mendalami tentang hubungan pengaturan sistem pemilu yang diadopsi dalam UU No. 8 Tahun 2012 Tentang Pemilu Anggota DPR, DPD dan DPRD pada pemilu tahun 2014 dengan praktek korupsi politik. Penelitian ini merupakan jenis penelitian sosio-legal yang menggabungkan norma hukum dengan aspek sosiologis dengan menggunakan metode pendekatan asas-asas hukum dan perilaku politik. Hasil penelitian memperlihatkan, bahwa pengaturan sistem pemilu proporsional terbuka (open list) berbasis suara terbanyak berkorelasi positif terhadap pratek korupsi politik. Karena sistem pemilu ini berbiaya mahal, akibatnya calon anggota legislatif melakukan aneka model kecurangan dalam pemilu yang dikualifikasikan sebagai praktek politik uang untuk mendapat dukungan pemilih. Motif korupsi politik yang dilakukan oleh anggota DPR dan DPRD adalah mengembalikan biaya mahal yang dikeluarkan saat pemilu. Model pembaruan pengaturan sistem pemilu untuk menciptakan pemilu antikorupsi politik adalah memurnikan sistem pemilu proporsional dengan merubah model pengaturan sistem proporsional terbuka terbatas (close list) dengan berbasis nomor urut.
\end{abstract}

Kata Kunci: korelasi pengaturan, sistem pemilu dan korupsi politik 


\section{A. Pendahuluan}

Pemilihan umum anggota DPR, DPD dan DPRD tahun 2014 telah berlangsung pada 9 April 2014 lalu. Ini adalah pemilu ke 4 (empat) pasca Orde Baru. Itulah sebabnya pemilu 2014 ini diharapkan dapat mengantarkan Indonesia mengakhiri transisi demokrasi menuju konsolidasi demokrasi. Sebab berdasarakan pengalaman empiris di banyak negara demokrasi, 3 (tiga) kali pemilu saja telah dapat menjadi pijakan bagi hadirnya konsolidasi demokrasi, yakni praktek demokrasi yang kian matang dan stabil.

Sejak berakhirnya pemerintah rezim Orde Baru (Orba) tahun 1998 hingga hadirnya pemerintahan demokrasi baru hasil pemilu 1999, 2004, dan 2009 di era Reformasi seharusnya bangsa ini telah menyudahi era transisi demokrasi. Sebuah era yang menyisakan waktu berselang antara rezim otoriter (Orba) dengan rezim demokrasi, yang ditandai oleh berakhirnya rezim otoriter lama dan hadirnya Orde Reformasi dengan aneka kelembagaan demokrasi dan politik baru yang disyahkan menurut konstitusi (UUD 1945) hasil amandemen. (Riwanto, Agus, 2014: 6).

Itulah sebabnya pemilu 2014 lalu adalah momentum berharga bagi bangsa Indonesia untuk menyongsong era konsolidasi demokrasi, yakni stabilisasi, institusionalisasi, dan legitimasi demokrasi, serta keyakinan yang tumbuh dari semua elit politik dan masyarakat untuk menjadikan demokrasi sebagai satu-satunya cara dalam mengelola dan mengakhiri aneka problematika kebangsaan dan kenegaraan di sebuah negara (the only game in town). (Prezeworski, Adam, 1991:26).

Desain pemilu di Indonesia pasca reformasi tahun 1999, 2004 dan 2009 selalu mengalami perubahan dan perkembangan yang signifikan. Perubahan paket UU Politik dalam setiap pemilu ini membuktikan, bahwa telah terjadi perubahan sosial politik di Indonesia yang menuntut diakomodasi dalam pemilu. Karena adanya pengaruh dan interaksi yang tak terelakkan dari perkembangan masyarakat global. Dari sudut antropologi hukum ini adalah akibat dari adanya mobilitas politik dan hukum yang disebabkan oleh bergeraknya sejumlah aktor baik orang maupun organisasi yang bergerak dari satu negara ke negara lain.(Bechmann-, Franz von Benda, Bechmann-, Keebet von Benda, dan Anne Griffiths, 2005: 2-3). 
Sebagai negara demokrasi baru Indonesia belum memiliki peraturan pemilu yang stabil. Baik dalam arti sistem pemilu (electoral laws), maupun dari aspek proses penyelenggaraan pemilu (electoral process). (Mahfud MD, Moh, 2010:74).

Pengaturan sistem pemilu yang digunakan dalam penyelenggaraan pemilu tahun 2014 berdasarkan ketentuan Pasal 215 huruf a UU No.8 Tahun 2012 Tentang Pemilu Anggota DPR, DPD dan DPRD yang menyatakan bahwa, calon terpilih anggota DPR, DPRD Provinsi dan DPRD Kabupaten/Kota ditetapkan berdasarkan calon yang memperoleh suara terbanyak. Ketentuan dalam pasal ini sesungguhnya merupakan kelanjutan yang diadopsi dari pengaturan pemilu tahun 2009 berdasarkan ketentuan dalam UU No.10 Tahun 2008 Tentang Pemilu Anggota DPR, DPD dan DPRD. Dengan demikian pengaturan sistem pemilu di Indonesia berdasarkan norma dalam kedua UU ini adalah menganut model sistem pemilu proporsional terbuka murni, dimana penentuan calon terpilih berdasarkan suara terbanyak. Berbeda dengan pemilu tahun 2004 berdasarkan ketentuan UU No. 23 Tahun 2003 Tentang Pemilu Anggota DPR dan DPRD dan pemilu tahun 1999 berdasarkan ketentuan UU No. 3 Tahun 1999 yang menganut sistem pemilu proporsional terbuka terbatas, dimana penentuan calon terpilih berdasarkan pada nomor urut.

Sistem pemilu dengan penentuan calon terpilih berdasarkan suara terbanyak ini pada gilirannya melahirkan sistem pemilu liberal yang menitikberatkan pada kekuatan individu calon dan menafikan peran partai politik. Parpol hanya sekedar dijadikan alat dan kendaraan politik selebihnya kompetisi dalam pemilu terjadi antar individu calon. Padahal prinsip dasar sistem pemilu proporsional adalah mengutamakan peran parpol dan seharusnya kompetisi dalam sistem ini adalah kompetisi antar parpol. Sehingga tema kompetisi dalam kampanye adalah memperdebatkan ide, gagasan, visi, misi dan program parpol.

Realitasnya sistem proporsional terbuka (open list) dengan berbasis suara terbanyak melahirkan melahirkan model kompetisi antar calon yang tak sehat dan hanya bertujuan meraup suara sebanyak-banyaknya dari pemilih dengan mengandalkan pada uang dan popularitas. Itulah mengapa kecurangan pemilu dengan sistem ini lebih didominasi oleh politik uang (money politic) dalam berbagai varian mulai dari, pemberian uang tunai, pemberian pulsa, pembagian polis asuransi, pembagian sembako, hingga perbaikan infrastruktur publik oleh calon untuk meraih simpati konstituen menjelang pemilu. (Riwanto, Agus, 2014:6).

Akibatnya sistem pemilu ini menjadi pemilu yang sangat mahal dalam sejarah pemilu di Indonesia setidaknya jika dibandingkan dengan sistem pemilu proporsional tertutup 
(closed list) berbasis nomor urut di Era Orde Baru dan di Pemilu era Reformasi tahun 1999 dan 2004.

Mahalnya biaya untuk meraih kursi di DPR dan DPRD ini telah mendorong secara sistematis para politisi untuk melakukan korupsi politik, yakni tindakan melawan hukum dan moral karena menyalahgunakan kekuasaan dan kewenanagan yang dimiliki seseorang untuk kepentingan dirinya, kelompok atau pihak-pihak lain yang untuk saling mencari keuntungan secara ekonomi maupun politik. Karena pelakunya adalah pejabat publik maka perilakunya dapat disebut sebagai korupsi politik (political corruption). (Alkostar, Artidjo, 2010: 16-17).

Di titik inilah mengapa pasca pemilu korupsi politik yang dilakukan oleh politisi di Indonesia menguat salah satunya karena biaya yang dikeluarkan saat pemilu tidak sebanding dengan pendapatan yang diperoleh saat menjabat menjadi politisi. (Riwanto, Agus, 2013:6). Karena itu, sesungguhnya pengaturan sistem pemilu proporsional terbuka (open list) berbasis suara terbanyak berkorelasi positif terhadap lahirnya korupsi politik di Indonesia.

\section{B. Pokok Masalah}

Berdasarkan realitas tersebut maka penelitian ini akan menjawab berbagai persoalan yaitu:

1. Mengapa pengaturan sistem pemilu di Indonesia memilih sistem pemilu proporsional terbuka (open list) berbasis suara terbanyak?

2. Apa dan bagaimana korelasi pengaturan sistem pemilu tersebut dengan korupsi politik di Indonesia?

3. Bagaimanakah upaya menciptakan pengaturan sistem pemilu yang antikorupsi politik di Indonesia?

\section{Metode Penelitian}

Jenis penelitian ini adalah diskriptif dan eksplanatoris. Ini juga merupakan penelitian hukum sosio-legal atau penelitian non-doktrinal, yakni penelitian yang diterapkan khusus pada ilmu hukum yang menggabungkan antara aspek normatif dan empiris. (Sugeng, Istanto, F, 2007: 29). Yakni, norma hukum dalam Pasal 215 huruf a UU No.8 Tahun 2012 Tentang Pemilu Anggota DPR, DPD dan DPRD yang mengatur sistem pemilu proporsional berbasis suara terbanyak pada pemilu 2014 dan pelaksanaan norma ini dalam penyelenggaraan pemilu tahun 2014. 
Adapaun Hukum yang dimaksud dalam penelitian ini adalah asas-asas kebenaran dan keadilan yang bersifat kodrati dan berlaku universal, ini merupakan karakteristik penalaran yang berorientasi filsafat. (Wigyosoebroto, Soetandyo, 2013:13-15).

Pendekatan yang digunakan dalam penelitian ini adalah pendekatan politik, yakni perpektif yang digunakan dalam mengkaji fenomena politik dalam realitas hukum tatanegara. Penelitian ini hanya menggunakan pendekatan tingah laku (behavioral approach). (Marsh, David and Stoker, Gerry (ed), 1995: 189-202).

Penelitian ini memusatkan pada sumber bahan hukum dan data kepustakaan atau dokumen (library research). Penelitian kepustakaan dimaksudkan untuk memperoleh data sekunder, berupa bahan hukum primer, sekunder dan tersier. Dilanjutkan dengan menginventarisir, meneliti atau menguji bahan-bahan hukum atau data tertulis yang relevan dengan objek penelitian.

\section{Hasil Penelitian dan Pembahasan}

\section{Pengaturan Sistem Pemilu Proporsional Berbasis Suara Terbanyak}

Sistem pemilu yang digunakan pada setiap negara sesungguhnya dirancang dalam rangka mewujudkan tujuan utama dari pemilu, menurut Aurel Croissant tujuan pemilu ada 3 (tiga), (Crissant, Aurel, 2002: dalam Surbakti, ramlan, dkk, 2011: 13).

Yaitu: (i) keterwakilan politik, (political representation), dalam arti kelompokkelompok dalam masyarakat dapat terwakili di parlemen, baik dari aspek geografis, fungsional dan diskriptif; (ii) integrasi politik (political integration), yakni stabilitas politik dapat terjadi karena adanya kesepahaman antara partai politik dan masyarakat terhadap partai politik sehingga konflik politik dapat direma secara efektif lewat lembaga perwakilan; dan (iii) membantu terbentuknya pemerintahan yang efektif (effective government), yakni adanya jaminan pada stabilitas pemerintahan dan kemampun pemerintah dalam menjalankan roda pemerintah.

Dalam prakteknya tidak semua Negara mampu mewujudkan ketiga tujuan pemilu itu. Indonesia telah bereksperimen untuk melaksanakan tiga tujuan itu. Pada pemilu Orde Baru tujuan pemilu lebih diarahkan pada menciptakan integrasi politik nasional dan terbentuknya pemerintahan efektif. Itulah mengapa pemilu era Orde Baru hanya diikuti oleh 2 partai politik (PDI dan PPP) dan 1 golonngan Karya yang tujuannya agar pemerintah efektif dan menghindari instabilitas politik. Faktanya pemerintah Orde Baru sangat stabil dan dapat berlangsung 32 tahun. Namun era ini melupakan tujuan keterwakilan politik, akibtanya 
semua potensi politik massa diberanggus dan melahirkan massa mengambang (floating mass). (Mahfud MD, Moh, 2010: 214-262).

Sedangkan di era Reformasi tujuan pemilu diarahkan pada keterwakilan politik yang dibuktikan dengan munculnya multipartai pada setiap pemilu, namun melupakan tujuan integrasi dan efektifitas pemerintah. Akibtanya sejak pemilu 1999 hingga 2014 lalu selalu terjadi instabilitas politik di DPR RI dan pemerintah presidensial tak berjalan efektif karena tersandera oleh himpitan kepentingan partai-partai di DPR. (Yuda, Hanta AR, 2010: 43-54).

Sejak pemilu pertama pada tahun 1955 hingga pemilu akhir Orde Baru pada tahun 1997 sistem pemilu yang digunakan adalah sistem pemilu proporsional dengan varian tertutup (closed list), yakni peran parpol dalam pemilu kuat untuk menempatkan calon dan penentuan calon di dasarkan pada nomor urut. Sedangkan pada pemilu pertama era Reformasi pada tahun 1999 masih mengadopsi sistem pemilu warisan Orde Baru hanya merubah varian penentuan calon terpilih dengan mengenalkan model stabbus accord, yakni kesepakatan antar parpol bila terdapat sisa suara untuk diberikan pada calon dari parpol dengan nomor urut tertentu berdasarkan kesepakatan pmpinan parpol.

Adapun pemilu tahun 2004 masih menggunakan sistem pemilu proporsional tertutup seperti pada pemilu 1999, dengan menetapkan varian model penentuan kursi berdasarkan perolehan parpol di daerah pemilihan (Dapil) dan penentuan calon terpilih di dasarkan pada Bilangan Pembagi Pemilih (BPP). Jika ada calon yang dapat memenuhi 100 \% BPP maka calon tersebut secara otomatis ditetapkan menjadi calon terpilih, jika tidak calon yang dapat meme nuhi BPP, maka calon terpilih ditentukan berdasarkan daftar nomor urut yang ditentukan oleh partai politik dalam surat suara suara. Jika masih terdapat sisa kursi dibagikan pada partai politik yang memperoleh sisa suara terbesar (large remainders) berturut-turut sampai semua kursi terbagi habis di daerah pemilihan (Dapil).

Sistem pemilu tahun 2004 ini sebenarnya hendak dipertahankan pada pemilu tahun 2009, namun karena model ini diduga memperkuat oligarkhi elit parpol dalam pencalonan, akibtanya proses pencalonan dari nominasi hingga penetapan calon dalam internal parpol rentan dipermainkan dengan harga yang sangat mahal terutama untuk dapat menduduki nomor urut berpotensi terpilih biasanya antara urut 1 hingga 3 dalam list surat suara. (Haris, Syamsudin (editor), 2005: 1-28). I

Itulah sebabnya mengapa sistem ini tidak digunakan lagi pada pemilu tahun 2009 dan memilih sistem pemilu proporsional terbuka (open list) berbasis suara terbanyak. Salah satu maksudnya adalah agar caleg terpilih lebih representatif dan legitimasinya jauh lebih kuat 
karena sudah selayaknya yang berhak mendapat kursi adalah caleg yang memang memperoleh dukungan rakyat yang paling banyak. Model ini juga lebih demokratis, karena yang dijadikan ukuran pemenangnya adalah yang memperoleh suara terbanyak, baik perolehan suara terbanyak mutlak maupun terbanyak sederhana.

Sistem pemilu 2009 yang berbasis pada penentuan caleg terpilih berdasarkan pada suara terbanyak ini bermula dari norma baru yang diciptakan oleh Mahkamamah Konstitusi, atas uji materiil (judicial review) Pasal 214 UU No.10 Tahun 2008 tentang Pemilu Anggota DPR, DPD dan DPRD. Pasal 214 menyatakan, bahwa calon terpilih anggota DPR, DPRD Provinsi, dan DPRD Kabupaten/Kota ditetapkan berdasarkan calon yang memperoleh suara sekurang-kurangnya $30 \%$ (tiga puluh perseratus) dari bilangan pembagi pemilih (BPP). Putusan MK No.22-24/PUU-VI/2008.

Dalam hal calon yang memenuhi ketentuan ini lebih banyak daripada jumlah kursi yang diperoleh parpol peserta pemilu, maka kursi diberikan kepada calon yang memiliki nomor urut lebih kecil di antara calon yang memenuhi ketentuan sekurang-kurangnya $30 \%$ (tigapuluh perseratus) dari bilangan pembagi pemilih (BPP).

Pembatalan berlakunya Pasal 214 UU No.10/2008 ini jelas memperlemah pelembagaan partai politik, karena peran parpol jadi menghilang dalam penentuan caleng terpilih. Padahal sejatinya ketentuan Pasal 214 ini adalah dalam rangka untuk memberikan porsi yang seimbang antara peran parpol dan pemilih. Parpol diberi kewenangan dalam menempatkan caleg berdasarkan nomor dengan kriteria yang telah disepakati dalam AD/ART Parpol dan kedaulatan pemilih dihargai sehingga terdapat angka 30 \% BPP sebagai bentuk penghargaan kepada suara pemilih.

Sistem proporsional maksudnya adalah penentuan pemenang di suatu daerah pemilihan (Dapil), didasarkan pada perolehan kursi parpol bersangkutan dengan cara memperhitungkan perolehan suara sah parpol dibagi dengan angka bilangan pembagi pemilih (BPP), maksud dengan daftar calon terbuka berarti parpol mencantu nama-nama calon anggota DPR dan DPRD pada kertas suara untuk dipilih langsung oleh konstituen. (Riwanto, Agus, 2007: 283).

Bilangan pembagi pemilih (BPP), adalah bilangan yang diperoleh dari pembagian jumlah suara sah dengan jumlah kursi di suatu daerah pemilihan untuk menentukan jumlah perolehan kursi partai politikpeserta pemilu dan terpilihnya anggota DPR dan DPRD.

Pembatalan Pasal 214 UUU No.10/2008 oleh MK ini telah melahirkan norma baru sistem pemilu tahun 2009 dari sistem proporsional “terbuka terbatas” menjadi “terbuka 
murni”. Dalam prakteknya putusan MK ini tidak berpengaruh signifikan terhadap pengurangan praktek money politic dalam proses pencalonan antar pengurus parpol dan caleg, begitu pula tidak dapat menghilangkan oligarki elit parpol dalam menentukan caleg, karena putusan Mahkamah Konstitusi lahir setelah parpol menetapkan Daftar Calon Sementara (DCS) dan KPU telah menetapkan Daftar Calon Tetap (DCT).

Sistem pemilu proporsional terbuka (open list) dengan berbasis suara terbanyak ini dipertahankan dalam pemilu tahun 2014 berdasarkan ketentuan Pasal 215 huruf a UU No.8 Tahun 2012 Tentang Pemilu Anggota DPR, DPD dan DPRD yang menyatakan bahwa, calon terpilih anggota DPR, DPRD Provinsi dan DPRD Kabupaten/Kota ditetapkan berdasarkan calon yang memperoleh suara terbanyak.

\section{Korelasi Pengaturan Sistem Pemilu dengan Korupsi Politik}

Sistem pemilu proporsional berbasis suara terbanyak ini melemahkan pelembagaan sistem kepartaian. Malah sebaliknya putusan ini telah meminimalkan loyalitas calon pada parpol, sebaliknya garis komando parpol terputus dan akan melahirkan krisis kewibawaan parpol. Sistem pemilu ini telah membuka peluang bagi calon-calon popular untuk dipilih tanpa kompetensi, ketimbang calon-calon berkompeten tapi tidak popular, suara terbanyak belum tentu identik dengan kualitas politisi yang duduk di DPR. Dari sisi sirkulasi elite sistem suara terbanyak memang sangat baik, namun dari sisi kualitas belum menjamin kualitas lembaga DPR.

Sistem suara terbanyak juga akan menimbulkan individualisme para politisi, selama demokrasi belum matang, akan saling sikut, memakan atau kanibalisme di internal parpol sendiri.

Sistem pemilu ini telah melawan arus kebiasaan terhadap pilihan sistem pemilu proporsional di dunia. Kebanyakan sistem proporsional di dunia terutama di negara-negara demokrasi baru memakai varian daftar tertutup (closed list of proportional representation), artinya bahwa urutan caleg yang dipilih berdasarkan daftar urut yang ditentukan oleh parpol melalui seleksi ketat dan demokratis. Sistem ini ditujukan untuk memperkuat sistem kepartaian, terutama agar parpol dapat berperan cukup besar. Karena memang peserta pemilu dalam sistem proporsional adalah parpol, bukan individu. (Surbakti, Ramlan, 2009 dalam P. Setyo, Widya dan Pulungan, Halomoan, 2009:31).

Sistem pemilu berbasis suara terbanyak ini, kian menegaskan format demokrasi langsung dan meneguhkan demokrasi ekstra liberal, yakni menempatkan individu yang total 
bersaing dengan yang lain, partai hanya menjadi kendaraan. Cara ini cenderung melahirkan liberalism politik atau "persaingan bebas politik sebebas-bebasnya”. Karena itu, semua parpol peserta pemilu tahun 2009 tidak lagi memiliki kontrol ketat penentu terpilihnya caleg, nomor urut caleg menjadi tidak relevan, tergantikan oleh kekuatan individu caleg, dan parpol hanya berfungsi sebagai merek politik. (Alfan, M. Alfian, 2009: 30).

Bahkan menurut Mietzner, sistem penentuan calon terpilih berdasarkan suara terbanyak telah menjadikan pemilu menjadi sangat mahal dan melahirkan problem yang multikompleks. (Mietzner, Marcus, 2009: 19).

Dengan demikian pengaturan sistem pemilu Pemilu 2009 dan 2014 yang menganut sistem pemilu proporsional terbuka berbasis penentuan pemenang dalam kompetisi pemilu berdasarkan suara terbanyak ini telah memprovokasi lahirnya model kompetisi antar calon dalam pemilu yang tak sehat. Itulah sebabnya orientasi meraih suara terbanyak telah mendorong calon legislatif (Caleg) banyak melakukan kecurangan untuk merayu pemilih dalam aneka bentuk, seperti: pembagian uang cash antara Rp. 20.000-Rp.200.000 per pemilih, pemberian door prize, bantuan sosial, polis asuransi, pembelian pulsa, pemberian pakaian, pengobatan gratis hingga pengaspalan jalan dan perbaikan fasilitas publik. Aneka bentuk kecurangan ini dapat dikualifikasikan sebagai politik uang (money politics). (Riwanto, Agus, 2014:6).

Modus yang dirancang para Caleg dalam menyebar uang dan material ini: mulai dari serangan fajar, serangan dhuha, bahkan serangan sebulan sebelum hari H 9 April 2014. Yang unik ada Caleg tertentu yang telah memiliki data TPS, jumlah pemilih terdaftar di DPT lengkap dengan alamatnya yang siap untuk di datangi door to door dan face to face setahun sebelum pemilu. Belum lagi Caleg yang memanfaatkan agen penjual hand phone (HP) untuk diminta nomor HP pemilih yang siap dikirimi ajakan memilih melalui SMS yang jumlah puluhan ribu. Bahkan masih ada caleg tertentu yang kreatif mengratiskan pemilih makan bakso, mie ayam, sampai prasmanan pasca pencoblosan. Model ini nyata telah menjungkirbalikkan ideologi pemilih dari datang ke TPS untuk menjadi sarana kedaulatan rakyat, berubah menjadi sarana mendaulatkan uang. (Riwanto, Agus, 2014:6).

Itulah sebabnya pengaturan sistem pemilu proporsional berbasis suara terbanyak ini telah membuat pemilu 2009 dan 2014 adalah pemilu yang paling mahal dalam sejarah pemilu di Indonesia. Misalnya, Lembaga Penyelidikan Ekonomi dan Masyarakat Universutas Indonesia (LPEM-FEUI) merilis biaya kampanye Caleg DPR mencapai Rp.1,2 miliar-Rp.4,6 miliar sedangkan Caleg DPD Rp.541 Juta- Rp. 1,3 miliar. (Kompas, 3 April 204).Sedangkan 
menurut liputan Republika biaya kampanye Caleg DPR RI mencapai Rp.787 Juta-Rp. 9,3 miliar dan Caleg DPR Propinsi mencapai Rp.320 juta-Rp.3 miliar. Rata-rata per Caleg mengeluarkan dana Rp.1,18 miliar. Dana sebesar itu untuk keperluan: percetakan, tekstil, transportasi dan komunikasi, jasa komunikasi media, dan pengerahan massa. (Kompas,24 Maret 2014).

Sungguh ini merupakan berita buruk dan sangat mengejutkan publik. Betapa boros dan irasionalitas biaya demokrasi elektoral kita. Ini adalah pemilu termahal dalam sejarah pemilu di Indonesia. Karena menurut data di KPU RI terdapat 2.00.000 orang caleg DPR, DPD dan DPRD seluruh Indonesia, jika rata-rata mengeluarkan uang sebesar Rp. 1,18 miliar, maka sampai besok Rabu 9 April akan berputar uang sebesar Rp. 227 triliun di bumi Indonesia.

Di sinilah logikanya terdapat korelasi yang cukup kuat dan tak terbantahkan, mengapa megakorupsi politik (political corruption) pasti menguat pascapemilu di Indonesia. Karena para Anggota DPR dan DPRD harus mengembalikan modal uang yang dikeluarkan saat berkompetisi dalam pemilu. Fenomena maraknya politik uang dalam pemilu 2014 ni jelas menegaskan, bahwa aspek ekonomi telah mereduksi hakekat dan makna pemilu demokrasi.

Motif korupsi politik yang dilakukan politisi ini selain untuk mengembalikan modal saat kampanye dalam pemilu juga disebabkan tak jelasnya model pembiayaan organisasi partai politik untuk survavilitas partai. Sisi investasi finansial untuk memenuhi kebutuhan partai tak terbatas. Pada saat bersamaan, partai adalah institusi yang didesain tidak dengan motif mencari laba. Partai adalah institusi nirlaba, tetapi melibatkan investasi tak terhingga. (Pamungkas, Sigit, 2008: 4).

Sementara mengandalkan subsidi negara melalui bantuan APBN untuk partai politik tak mencukupi dan iuran anggota partai tak memadai. Maka tak ada cara lain selain harus memanfaatkan kader-kader partai politik di DPR untuk menjadi agen partai dalam mengisi kekosongan kas keuangan partai, begitu pula kader-kader partai yang menduduki jabatan menteri, staf ahli menteri dan utusan khusus menteri yang sebisa mungkin dapat menggelontorkan pundi-pundi uang ke kas partai tentu saja dengan memanfaatkan jabatan yang dimilikinya.

Sesungguhnya kedaulatan rakyat pada pemilu 2014 telah digantikan dengan kedaulatan uang. Realitasnya uang adalah aktor utama kemenangan parpol dan caleg dalam pemilu 2014 yang mengabaikan ide, gagasan dan platform politik. Itulah mengapa jarak ideologi antar Parpol peserta pemilu 2014 kian dekat bahkan sama. 
Boleh jadi kini ideologi tak lagi menjadi pedoman utama bagi pemilih dalam melakukan pilihan pada parpol tertentu, begitu pula para elit parpol dan caleg dalam mempengaruhi pemilih dan memasarkan parpol (political marketing) tak lagi berlandaskan ideologi parpol, melain berdasarkan sejumlah uang. Karena itu pemilu 2014 menjadi saksi sejarah betapa idelogi telah tergantikan oleh uang. Inilah masa senjakala ideologi.

\section{Pembaruan Sistem Pemilu Antikorupsi Politik}

Upaya ideal yang bisa dilakukan untuk menciptakan model pengaturan sistem pemilu yang antikorupsi politik adalah melakukan "rekayasa sistem pemilihan” sesuai dengan prioritas problem politik di suatau negara. Dalam konteks ini problem politik kita adalah memangkas sistem pemilu yang berkorelasi kuat dengan korupsi politik. (Wall, Alan, 2008: $6)$.

Untuk menambal kelemahan dari sistem pemilu tahun 2014 yang lalu, maka ke depan diusulkan model sistem pemilu proporsional dengan daftar calon terbuka berbasis nomor urut. Sistem ini diusulkan karena relatif mampu mengakomodasi makna proporsional dalam keterwakilan politik. Selain dalam rangka untuk memurnikan sistem proporsional, yakni memberikan peran partai politik untuk menyusun daftar calon melalui nomor, namun juga memberikan peran konstituen untuk memilih nama-nama calon sesuai yang dikehendaki.

Upaya operasional usulan sistem proporsional terbuka ini, yakni yang dimaksud proporsional adalah penentuan calon terpilih di suatu daerah pemilihan (Dapil) di dasarkan pada perolehan kursi partai politik bersangkutan dengan cara memperhitungkan perolehan kursi partai politik dibagi angka Bilangan Pembagi Pemilih (BPP). Adapun yang dimaksud dengan daftar calon terbuka berarti parpol mencantumkan nama-nama calon pada kertas suara untuk dipilih langsung oleh konstituen.

Kelebihan dari sistem proporsional dengan calon terbuka dengan varian nomor urut (closed list system) ini adalah sebagai berikut:

Pertama, meningkatnya loyalitas calon pada institusi partai politik, ini berarti segaris dengan makna mengkuatkan sistem kepartaian, dimana partai akan menempati peran strategisnya dalam mengelola dan mengatur kader-kadernya. Kedua, meningkatkan gairah dan semangat untuk menjadi pengurus partai politik. Sehingga partai akan menjadi wadah organisasi politik yang sesungguhnya bukan saja untuk merebut dan mempertahankan 
kekuasaan, akan tetapi juga upaya memperkuat ideologi, program, dan pengkaderan yang memadai.

Ketiga, akan membuka peluang bagi kader partai politik yang berkualitas untuk dapat terpilih dalam pemilu, karena kecerdasan pengurus partai politik dalam menempatkan pada nomor urut kecil pada daerah pemilihan tertentu.

Keempat, sistem ini akan menghasilkan harmoni dalam pengaturan pergantain antar waktu (PAW) anggota DPR. Dimana sejak pemilu masa Orde Baru hingga masa Orde Reformasi dalam UU Susunan dan dan Kedudukan MPR, DPR dan DPRD porsi peran partai politik selalu lebih dominan dalam PAW terhadap calon anggota DPR/DPRD ketimbang konstituen atau pemilih. Jika keterpilihan calon berdasarkan suara terbanyak seperti dalam pemilu tahun 2009, bukan melalui BPP dan nomor urut, maka seharusnya PAW atas calon diharmonikan dengan model suara terbanyak, yakni memberi porsi yang besar pada pemilih untuk mengganti (PAW) calon. Namun realitasnya, dalam PAW otoritas partai politik cukup besar. Tak heran bila setiap PAW calon anggota DPR/DPR selalu menimbulkan masalah dan tak jarang selalu di gugat di pengadilan. Salah satu klausul gugatannya selalu terletak pada gugatan dominasi parpol dalam PAW. Karena itu sistem proporsional dengan calon terbuka akan memberi solusi yang tepat dalam menentukan model PAW anggota DPR dan DPRD. Sebab keterpilihan calon berdasarkan nomor urut atau BPP, maka PAW dilakukan oleh partai politik pula.

Kelima, sistem ini akan memudahkan penyelenggara pemilu untuk melakukan rekapitulasi. Sehingga berpotensi mengurangi kesalahan-kesalahan teknis lainnya. Dengan demikian secara otomatis tidak akan banyak menimbulkan pelanggaran pidana maupun administrasi dalam pemilu. Keenam, akan dapat memangkas model kompetisi yang liberal antar calon dalam satu partai dengan lebih mengutamakan pada politik uang ketimbang kompetisi pada gagasan dan ide-ide perubahan. Seharusnya peran partai politik dalam pemilu lebih besar daripada sekedar mengajukan daftar calon. Parpol seharusnya lebih beran aktif dalam mengeluarkan dana daripada partai dan peran orang tidak mengalahkan peran partai sebagai peserta pemilu. Dengan demikian sistem proporsional dengan daftar calon terbuka yang diajukan ini akan akan kian mempurifikasikan sistem proporsional.

\section{Kesimpulan}

1. Argumentasi sosiolologis mengapa sistem pemilu di Indonesia memilih sistem proporsional terbuka (open list) berbasis suara terbanyak berdasarkan ketentuan Pasal 215 
huruf a UU No.8 Tahun 2012 Tentang Pemilu Anggota DPR, DPD dan DPRD pada pemilu 2014 adalah untuk mewujudkan salah satu tujuan pemilu, yaitu meningkatkan representasi politik yang ditandai dengan kian dekatnya caleg dengan pemilih, dan memiliki legitimasi kuat karena sudah selayaknya yang berhak mendapat kursi adalah caleg yang memperoleh dukungan rakyat yang paling banyak. Model ini juga lebih demokratis, karena yang dijadikan ukuran pemenangnya adalah yang memperoleh suara terbanyak, baik perolehan suara terbanyak mutlak maupun terbanyak sederhana.

2. Pengaturan sistem pemilu proporsional terbuka (open list) berbasis suara terbanyak ini melawan arus kebiasaan terhadap pilihan sistem pemilu proporsional di dunia yang menggunkan varian daftar tertutup (close list) berbasis nomor urut, artinya penentuan caleg terpilih berdasarkan daftar urut yang ditentukan oleh parpol melalui seleksi ketat dan demokratis. Sistem ini ditujukan untuk memperkuat sistem kepartaian, terutama agar parpol dapat berperan cukup besar. Karena peserta pemilu dalam sistem proporsional adalah parpol, bukan individu. Sistem pemilu ini selain melahirkan model kompetisi liberal, materialistik juga berbiaya mahal. Sistem pemilu ini berkorelasi kuat dengan korupsi politik (political corruption) pascapemilu di Indonesia. Motif korupsi politik para Anggota DPR dan DPRD adalah untuk mengembalikan modal uang yang dikeluarkan saat berkompetisi dalam pemilu. Fenomena maraknya politik uang dalam pemilu menegaskan, bahwa aspek ekonomi telah mereduksi hakekat dan makna pemilu demokrasi.

3. Upaya pembaruan yang dapat dilakukan ntuk mewujudkan sistem pemilu antikorupsi politik adalah memurnikan sistem pemilu proporsional dengan model pengaturan sistem pemilu proporsional terbuka (open list) terbatas dengan berbasis nomor urut dan tidak lagi berbasis suara terbanyak.

\section{DAFTAR PUSTAKA}

Agus Riwanto. 2007. Ensiklopedia Pemilu,Analisis Kritis Intropeksi Pemilu 2004, Menuju Agenda Pemilu 2009, Pustaka Pelajar,Yogyakarta. -2013. “Parpol Biang Korupsi Sistemik”, Koran Jakarta, 9 Desember 2013. 2014. "Pilres 2014 Menuju Konsolidasi Demokrasi”, Media Indonesia, 7 Juli 2014.

-2014, “Menyoal Kecurangan Pemilu 2014”, Republika, 30 April 2014.

2014, “Tiga Faktor Golput Pemilu 2014 Turun”, Koran Kontan, 13 Mei 2014. 2015. "Penegakan Hukum dan Kecurangan Pemilu 2014”, Media Indonesia, 24 April 2015. 
Artidjo Alkostar. 2010. Korupsi Politik Di Negara Modern. Yogyakarta : FH UII Press.

M Alfan Alfian. 2009 “Otokritik Demokrasi Ekstra Liberal Pemilu 2009”, Jurnal Negarawan, No.11 Tahun 2009, Sekretariat Negara Republik Indonesia, Jakarta.

Benda-Bechmann, Franz Von, Keebet von Benda Bechmann, dan Anne Griffiths. 2005. Mobile People, Mobile Law, Exspanding Legal Relations in Contracting World, England, Ashgate.

Croissant, Aurel. 2002, Election Politics in Southeast and East Asia, Fredrich-Ebert-Stiftung. Singapore.

F. Sugeng Istanto. 2007. Penelitian Hukum. Yogjakarta : CV Ganda.

Hanta Yuda AR. 2010. Presidensialisme Setengah Hati: Dari Dilema Ke Kompromi. Jakarta : PT Gramedia Pustaka Utama.

Marsh, David, and Gerry Stoker (ed). 1995. Theory and Methods In Political Science, Macmillan Press Ltd, Hampshire and London.

Mietzner, Marcus. 2009. “Indonesia's 2009 Election: Populism, Dynesties, and The Consolidated of the Party System, Analysis”, Paper, Lowy Institute for International Policy, Sydney, May.

Moh Mahfud MD. 2010. Politik Hukum di Indonesia. Jakarta : PT.Rajagrafindo Persada.

Przeworski, Adam. 1991. Democracy and the Market: Political and Economic Reforms in Eastern Europe and Latin America, Cambridge: Cambridge University Press.

Putusan Mahkamah Konstitusi Republik Indonesia (MKRI) No.22-24/PUU-VI/2008, tentang Pembatalan Pasal 214 UU No.10/2008, tanggal 19 Desember 2008.

Ramlan Surbakti. 2009. "Representasi Kepentingan Rakyat Pada Pemilu Legislatif 2009”, dalam Widya P.Setyanto dan Halomoan Pulungan, 2009, Representasi Kepentingan Rakyat pada Pemilu Legislatif 2009, Dinamika Politik Lokal di Indonesia. Salatiga : Yayasan Percik-Ford Foundation.

Ramlan Surbakti dkk. 2011. Menyederhanakan Waktu Pemilu: Pemilu Nasional dan Pemilu Daerah, Kemitraan bagi Pembaruan Tata Pemerintahan. Jakarta.

Sigit Pamungkas. 2008. “Korupsi dan Politikus”, Kompas, 7 Agustus 2008.

Soetandyo Wigyosoebroto. 2013. Hukum Konsep dan Metode. Malang Intrans Publishing.

Syamsudin Haris (editor). 2005, Pemilu Langsung Di Tengah Oligarki Partai: Proses Nominasi Dan Seleksi Calon Pemilu 2014, PT Gramedia Pustaka Utama, Jakarta.

Wall, Alan, 2008, Engineering Electoral Systems: Problems and Possibilities and Pitfalls, NIMD Knowledge, Den Haag.

Kompas, 3 April 2014.

Republika, 24 Maret 2014. 